\title{
Analysis of the Service Performance of a Driving License at the Traffic Unit of West Kutai Resort Police
}

\author{
Gede Pasek Muliadnyana*, Hardi Warsono \& Ida Hayu Dwimawanti \\ Public Administration Study Program, Faculty of Administrative Sciences, \\ Diponegoro University, Indonesia
}

Received: 14 September 2019; Reviewed: 18 September 2019; Accepted: 09 April 2020

* Coresponding Email: pasekm77@gmail.com

\begin{abstract}
Driving license services in West Kutai were carried out by the Driving License Administration Service Unit. Based on the final report of Kutai Barat Police in 2016, it was noted that the issuance target was not achieved and the issuance of driving licenses decreased from 45,423 issued in 2015 to 36,086 SIMs issued in 2016. The objective of this study was to analyze the service performance of driving licenses at the Traffic Police. Kutai Barat and its supporting factors, inhibiting factors and efforts to improve its performance. Service performance was seen through service performance indicators of productivity, responsiveness, responsibility and accountability. The supporting and inhibiting factors were seen through human resources, organizational culture and community views. Meanwhile, efforts to improve were seen through efforts to increase work and plan for work improvement activities. The research method used was descriptive qualitative. The results indicates that the performance of the Traffic Unit of West Kutai Police was good, the supporting factors for the performance were organizational culture and community views, while the inhibiting factor was human resources.
\end{abstract}

Keywords: Performance; Driving License; Traffic Unit of West Kutai Police.

How to Cite: Muliadnyana, G.P., Warsono, H., \& Dwimawanti, I.H., (2021). Analysis of the Service Performance of a Driving License at the Traffic Unit of the Kutai Barat Resort Police. Jurnal Administrasi Publik (Public Administration Journal), 11 (1): 69-76. 


\section{INTRODUCTION}

The bureaucratic reform journey of Indonesian National Police (Polri) has consistently demonstrated a commitment to the sustainability of internal reform in 3 aspects of the structural, instrumental and cultural fields. In its development, the bureaucratic reform program and the internal reform program have been integrated into the National Police Grand Strategy 2005-2025 which is divided into 3 stages. Currently, the National Police has entered the 3rd stage of the 2015-2019 National Police Strategic Plan with a strive for excellence strategy.

Based on the Executive Report of the Police Station / City Police / Metropolitan City / Metro Police in Indonesia Governance Index (ITK) in 2016, the results of the performance score of the main tasks and functions of the National Police was obtained the order of the function unit from the highest are Protection, Protection and Guarding / Linyomyan (6.07), Law Enforcement / Gakkum (6.02) and Maintenance of Community Security and Order / Harkamtibmas (5.92). These findings indicate that the scale of the assessment is classified as "moderate", therefore coordination and synergy between functional units is needed to strengthen the more important functions of the Police.

The ITK Executive Report shows that the Protection and Guardianship (Linyomyan) function has the highest value among the other three functions. However, for the quality of Polri's services to the public, ITK findings show that the governance performance and integrity of the Traffic Unit (Lantas) gets the lowest average score among all functional units. Especially for the Lantas function, there are 3 principles that fall into the sufficient category, namely behavior, transparency and accountability. But the other four principles, namely competence, responsiveness, fairness and effectiveness get red marks. In terms of responsiveness,
ITK findings show that there are still gaps in services, especially the implementation of arrangements, escorts and patrols (turjawali) and driving license services.

In accordance with Law No. 22 of 2009 concerning Traffic and Highways, the task of the Indonesian National Police (Polri) in serving the public, especially in terms of traffic is getting heavier. In accordance with Article 12 Law No. 22 of 2009, the duties and functions of the National Police for traffic units include 9 things, among others: 1) Testing and issuing motor vehicle licenses; 2) Carrying out registration and identification of motor vehicles; 3) Collection, monitoring, processing and presentation of traffic and road data; 4) Management of the control center for road traffic and road transportation information and communication systems; 5) Arranging, guarding, escorting and patrolling traffic; 6) Law enforcement includes taking action against violations and handling traffic accidents; 7) Traffic education; 8) Implementation of traffic management and engineering, implementation of village development, village community development and community empowerment; 9) Implementation of traffic operational management.

The nine duties and functions of the Traffic Police were carried out by every Police Station throughout Indonesia, including West Kutai Police. The driving license administration service in West Kutai was carried out by the SIM Administration Service Unit (SATPAS).

Table 1 shows the decrease in the number of driver license issuances. The target of increasing driving license issuance from 2015 to 2016 which should have increased by $15 \%$ was not achieved. The sharp drop in numbers from 45,423 driving licenses issued in 2015 to 36,086 driving licenses issued in 2016. This decrease in driving license issuance numbers raises separate questions regarding driving license services at West Kutai Police 
because if it was compared to the large number of motorized vehicles in West Kutai City, it was not corresponding. The following is the number of motorized vehicles in West Kutai City in 2011-2016.

Table 1

Development of SIM Issuance at Polres Kutai Barat

\begin{tabular}{lllll}
\hline No. & Type of Data & $\mathbf{2 0 1 5}$ & $\mathbf{2 0 1 6}$ & Percentage \\
\hline $\mathbf{1}$ & SIM A & 3,227 & $\mathbf{2 , 1 0 5}$ & $-\mathbf{1 , 1 2 2}(35 \%)$ decreased \\
\hline $\mathbf{2}$ & BI SIM & 488 & 417 & $-71(15 \%)$ decreased \\
\hline 3 & SIM BI.U & 56 & 25 & $-31(56 \%)$ fell \\
\hline 4 & SIM BII & 472 & 348 & $-124(27 \%)$ decreased \\
\hline 5 & SIM BII.U & 402 & 335 & $-67(17 \%)$ fell \\
\hline 6 & SIM C & 7,468 & 6,379 & $-1,089(15 \%)$ decreased \\
\hline 7 & SIM D & - & 0 & 0 \\
\hline AMOUNT & 12,113 & 9,609 & $2,504(21 \%)$ decreased
\end{tabular}

Source: West Kutai Police Final Report 2016

Table 2

Number of Motor Vehicles in West Kutai Regency 2011-2016

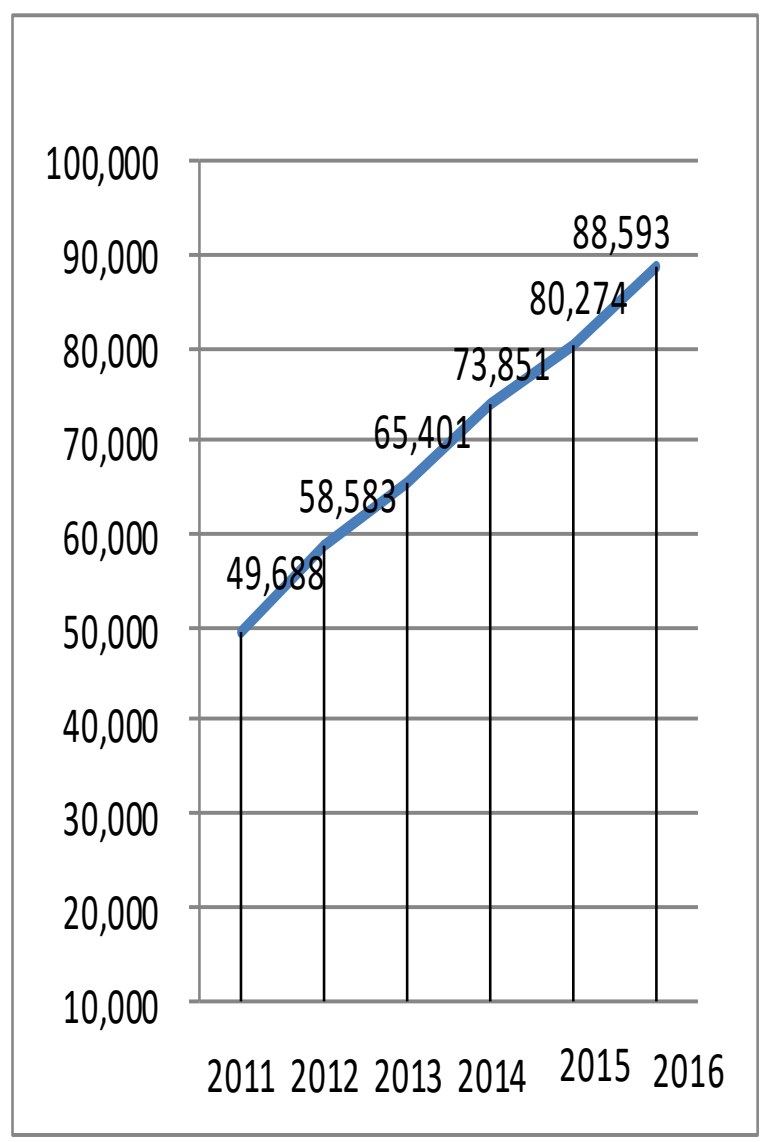

Source: Statistics Indonesia 2016

Table 2 shows the number of motorized vehicles in West Kutai Regency which has increased each year. When juxtaposed with the decrease in driving license issuance, it appears that there is a discrepancy occurring at traffic Unit. The increase in the number of existing vehicles should be followed by an increase in the number of applicants and / or the number of driving license issuances.

Several studies on service performance also explain that human resources also have a very large effect on services received by the public (Syardiansah, 2020; Sihombing et al., 2020; Syardiansah et al., 2020; Abduloh et al., 2020). Assessment of employee performance in a company, in this case human resources was also very influential on consumer demand which leads to an increase in the number of requests for cooperation (Sarumaha et al., 2017; Mora et al, 2020; Latief et al., 2019 ). Service performance of a government agency or institution did have service responsiveness was seen from the accuracy of service, friendliness and politeness, as well as the availability of complaint facilities for consumers (Siregar et al., 2016; Muslim et al., 2014; Simbolon and Sembiring 2015). Thus, human resources, namely personnel who served with their performance, greatly influenced the production and demand for goods.

Based on the problems in the background above, several problems can be identified from the productivity of the 
issuance of a driving license (SIM) at the Traffic Unit of West Kutai Resort Police, which had a very significant decline. There were still targets for the issuance of driving licenses at West Kutai Police that have not been achieved as planned. There were still complaints from the public as an applicant to get driving license services at the Satlantas Polres Kutai Barat.

Seeing the problems that occur, the objective of this study is to analyze the performance, supporting and inhibiting factors for driving license services and improving the performance of driving license services at the Traffic Unit of West Kutai Police.

\section{RESEARCH METHODS}

This study used a qualitative approach and was descriptive in nature. Qualitative research is methods for exploring and understanding the meaning that some individuals or groups of people perceive as derived from social or humanitarian problems. The qualitative research process involves important endeavors, such as asking questions and procedures, gathering specific data from participants, analyzing data inductively from specific themes to general themes, and interpreting the meaning of the data. The main final report of this research has a flexible structure or framework (Creswell, 2012).

This type of research used is descriptive research. Descriptive research is a study that intends to conduct examinations and measurements of certain symptoms (Fathoni, 2011). Descriptive research, which is a method of finding facts on the status of a group of people, objects, conditions, a system of thought or an event in the present with the correct interpretation (Sedarmayanti \& Hidayat, 2011)

The focus and locus of this research are: 1) the performance of a driving license (SIM) service at West Kutai Resort Police Traffic Unit to measure its productivity; 2) Factors that support and hinder the performance of the driving license (SIM) service at West Kutai Resort Police Traffic Unit in public services; 3) Efforts to improve the service performance of a Driving License (SIM) at the Traffic Unit of West Kutai Resort Police, in order to increase productivity and achieve unfulfilled targets.

\section{RESULTS AND DISCUSSION Driving License Service Performance Analysis}

Analysis of service performance to date is very important because it has a very strategic value in public activities (Rizal, 2011). According to Pasolong (2007), a public service is any activity carried out by government agencies to several people who have certain activities in each activity that must be beneficial for a group or unit, as well as offering satisfaction, even though the results are not tied to a physical product. Measuring the performance of the apparatus can be interpreted as an evaluation activity that assesses or observes the success and failure of the implementation of the tasks and functions assigned. On the other hand, measuring success or failure in carrying out its duties and functions is difficult to do objectively.

The productivity of West Kutai Police Traffic Police Driving License Service in 2016 has decreased. The target is also not in accordance with the mutual agreement between the Chief of Traffic Unit and West Kutai Police, namely an increase of $15 \%$. Based on the results of the analysis carried out, the driving license service at the Traffic Unit of West Kutai Police has carried out its responsibilities in achieving its goals and objectives. The decreasing productivity in 2016 occurred due to inadequate logistics governance. The main raw material in the form of cards has not been calculated correctly by the Traffic Police of West Kutai Police. Distribution of cards from 
the center had been delayed, causing scarcity in the the Traffic Unit of West Kutai Police.

The responsiveness of Traffic Unit of West Kutai Police driving license service can be seen from the accuracy of service, friendliness and politeness, the availability of complaint facilities. The results of the research show that the service performance of West Kutai Police driving license in providing driving license issuing services was fast and responsive. Several dimensions of responsiveness had good community ratings. Each of these dimensions had been implemented well by the West Kutai Police Traffic Unit driving license service.

Responsiveness of the implementation of driving license services by the Traffic Unit of West Kutai Police used Standard Operating Procedures as the basis of service. Standard Operating Procedure is made so that officers in serving service users can complete work properly without harming the community. Based on the Standard Operating Procedure (SOP), it is known that the driving license service staff at the Traffic Unit of West Kutai Police had carried out their duties and responsibilities properly. One of the dimensions of responsibility that did not fall into the good category here was the mismatch of service time to the community. The service time was not in accordance with the Standard Operating Procedure available at Traffic Unit of West Kutai Police driving license service.

The accountability of driving license services at Traffic Unit of West Kutai Police was shown by the existence of good legal guarantees and certainty. This legal guarantee and certainty can be seen and felt directly by the community, especially users of driving license services. The Traffic Unit of West Kutai Police in providing driving license services had provided or installed various boards and banners. The board containing the driving license issuance service flow / mechanism has been installed in such a way that it can be seen by the public who come to issue the driving license.

Regarding the service start time, the service staff had not shown a high discipline attitude which was oriented towards excellent service. People who came to apply for a driving license had to wait a few minutes until the service staff was ready to start their service.

\section{Supporting and Inhibiting Factors}

Internal factors, namely human resources at the Traffic Unit of Driving License service of West Kutai Police had not been good. The skills and knowledge possessed by the driving license service personnel of the Traffic Unit of West Kutai Police were based on technical abilities. Personnel did not receive training related to services so that their ability to serve them was not optimal. Most of the service staff of Traffic Unit of West Kutai Police driving license had a high school / vocational education background. Not only it, from the research results, there were some personnel who had poor performance.

External factors, namely the organizational culture at the Traffic Unit of driving lincse service of West Kutai Police had been good. Good communication had also been established between personnel and leaders. This interaction was shown from the motivation given by superiors to service staff every day to hold morning briefings. In addition, the leadership promised rewards for personnel who provided the best service performance, in order to increase their productivity. The results of the study indicates that the public's view of the work ethic of Traffic Unit of West Kutai Police driving license service was good. The community assessed that the officers had a high attitude and professionalism towards service to the community. Furthermore, norms in the 
form of improvement efforts that were continuously carried out by the Traffic Unit of West Kutai Police Driving License Service made the public had a positive view of the organization. However, there was some disappointment from the community, which reflected that the improvement efforts were still not optimal, namely the presence of a waiting room that was not representative.

\section{Service Performance Improvement Efforts}

Forms of performance improvement efforts / strategies. Based on the analysis of observations and research, Traffic Unit of West Kutai Police driving license service had made several efforts / strategies to improve performance as follows: 1) Implementation of FIFO (First In First Out) queues. The application of queues was carried out in order to implement a service justice system that did not consider the status, position, and position of driving license service users at the Traffic Unit of West Kutai Police. First In First Out is a queuing system where the first come is served; 2) Application of Computer-Based Theory Examination. Organizing theoretical exams using a computer, no longer using answer papers. Computer-based theory exams made it easier for people, because they only needed to press the choice of the desired answer. This system also made it easier for officers because it reduced the time for correcting answers; 3) Direct Complaints. The community can participate directly in the provision of driving license services organized by the Traffic Unit of West Kutai Police. This form of participation was by submitting suggestions / criticisms or complaints directly to the complaint room provided by the Traffic Unit of West Kutai Police.

Based on the results of research analysis through the phenomenon of driving license service performance in West Kutai Traffic Police, it can be seen the weaknesses and strengths in service. The service performance improvement activity plan was with several performance improvement steps that still need to be carried out and realized in activities / programs to overcome weaknesses in driving license services by the Traffic Unit of West Kutai Police. Based on the results of research analysis which can be used as a performance improvement program plan as follows: 1) Socialization of the need for making driving license to the public; 2) Providing sanctions for indiscipline of driving license service officers; 3) Consideration of eliminating the requirement for a driving certificate issued by a third party; 4) Open mobile driving license services.

\section{CONCLUSION}

The performance of driving license services at West Kutai Police had been good, seen from the four dimensions of performance, namely productivity, responsiveness, responsibility, and accountability used in this study. Although overall the implementation of service performance had been good, there were several obstacles that hinder the service, namely the mismatch of service time with the SOP and the cost outside the provisions which was quite expensive.

Supporting factors and inhibiting the performance of driving license services in the West Kutai Police which consist of internal and external factors. Supporting factors that come from internal, namely work culture which consists of 4 sub phenomena: (1) The culture of the driving license service unit was good, (2) Communication between superiors and subordinates was well established, (3) There were briefings that were held every day aimed at motivating members, (4) Availability of reward support for personnel with good performance. One supporting factor from the external environment is work ethic, where the 
work ethic of the officers and security guard (SATPAS) was already good.

Inhibiting factors, based on the analysis of the results of the study, there were three factors inhibiting the performance of SIM services at the Traffic Unit of West Kutai Police which come from internal factors, namely human resources. Some of the obstacles related to human resources, namely (1) the human resources of SIM services at the Traffic Unit of West Kutai Police were not good where the personnel were still high school / vocational graduates, (2) there were still personnel who were not well performing, (3) the skills and knowledge possessed by personnel in charge of providing driving license services were less than optimal.

Efforts to Improve Service Performance. To socialize the need to have a SIM for the community to increase the number of SIM issuances, provide training for officers on excellent service procedures, provide skills for officers to support performance, and impose a reward and punishment system as a form of motivation for the officers in carrying out their duties.

\section{BIBLIOGRAPHY}

Atmosoeprapto, K. (2001). Productivity of Atmosoeprapto, K. (2001). Produktivitas Aktualisasi Budaya Perusahaan. Jakarta: PT. Elex Media Komputindo.

Creswell. J. W. (2012). Research Design: Qualitative, Quantitative, and Mixed Methods Approaches. Edisi 4. D

Fathoni, A. (2011). Metodologi Penelitian dan Teknik Penyusunan Skripsi. Jakarta: PT Rineka Cipta.

Pasolong, H. (2007). Teori Administrasi Publik. Bandung: Alfabeta.

Rizal, M.F., (2011), Analisis Kinerja Aparatur Birokrasi (Studi pada Sekretariat Daerah Kabupaten Aceh Timur), Jurnal Administrasi Publik, 1 (2): 112-129

Sedarmayanti dan Hidayat, S. (2011). Metodologi Penelitian. Bandung: Mandar Maju.

Siregar, H., (2011), Analisis Kinerja Aparatur Birokrasi (Studi pada Bagian Sekretariat Daerah Kabupaten Labuhanbatu), Jurnal Administrasi Publik, 1 (1): 51-64.
Sarumaha, W.Y. Dewi, R. Batubara, B.M. (2017). Peran Camat dalam Mengawasi Kinerja Pegawai Di Kantor Camat Medan Denai Kota Medan. PERSPEKTIF, 6 (1): 25-36

Mora, Z., Suharyanto, A., Yahya, M., (2020). Effect of Work Safety and Work Healthy Towards Employee's Productivity in PT. Sisirau Aceh Tamiang, Budapest International Research and Critics Institute (BIRCI-Journal): Humanities and Social Sciences, 3(2): 753760.

Latief, A., Nurlina, N., Medagri, E., \& Suharyanto, A. (2019). Pengaruh Manajemen Pengetahuan, Keterampilan dan Sikap terhadap Kinerja Karyawan. JUPIIS: Jurnal Pendidikan IlmuIlmu Sosial, 11(2), 173-182. doi:https://doi.org/10.24114/jupiis.v11i2. 12608

Siregar, A.B., Kusmanto, H. Isnaini. (2016), Evaluasi Kinerja Kepala Sekolah Menengah Kejuruan Se-Kabupaten Langkat Tahun 2015, Jurnal Administrasi Publik, 6 (1): 1319

Muslim, N. dan Irwan N., (2014). Kinerja Aparat Desa Dalam Penyelenggaraan Pemerintahan Di Desa Pantai Labu Pekan, JPPUMA: Jurnal Ilmu Pemerintahan dan Sosial Politik UMA (Journal of Governance and Political UMA), 2 (2): 114-124

Simbolon, A.H., dan Walid M.S., (2015). Evaluasi Kinerja Badan Permusyawaratan Desa dalam Penyelenggaraan Pemerintahan Desa, JPPUMA: Jurnal Ilmu Pemerintahan dan Sosial Politik UMA (Journal of Governance and Political UMA), 1 (1): 143159.

Latief, A. Rosalina, D. \& Apiska, D. (2019). Analisis Hubungan Antar Manusia terhadap Kinerja Karyawan. Journal of Education, Humaniora and Social Sciences (JEHSS). 1 (3): 127-131.

Syardiansah, S. (2020). Pengaruh Kecerdasan Emotional Terhadap Kinerja Karyawan PT. Mopoli Raya Kecamatan Pematang Jaya. Journal of Education, Humaniora and Social Sciences (JEHSS), 3(1), 1-6. doi:https://doi.org/10.34007/jehss.v3i1.1 55

Sihombing, S., Nainggolan, E., Diafri, D., Sitompul, G., \& Anggoro, M. (2020). Pengaruh Kompetensi, Disiplin Dan Pengembangan Karier Terhadap Kinerja Karyawan PT. Asam Jawa Medan. Journal of Education, Humaniora and Social Sciences (JEHSS), 3(1), 273-280. doi:https://doi.org/10.34007/jehss.v3i1.3 03

Syardiansah, S., Latief, A., Daud, M. N., Windi, W., \& Suharyanto, A. (2020). The Effect of Job Satisfaction and Organizational Culture on 
Gede Pasek Muliadnyana, Hardi Warsono \& Ida Hayu Dwimawanti, Performance Analysis of License Services

Employee Performance of the Royal Hotel in East Aceh District. Budapest International Research and Critics Institute (BIRCIJournal): Humanities and Social Sciences, 3(2), 849-857.

Abduloh, O. A., Juhadi, A. S., Mohammad Syaifuddin, B. E., Wahid Wachyu Adi Winarto, N. A., Mubtadi, W., Hendri Hermawan Adinugraha, A. P., ... \&
Muhammad Masruri, N. A. (2020). Effect of Organizational Commitment toward Economical, Environment, Social Performance and Sustainability Performance of Indonesian Private Universities. PalArch's Journal of Archaeology of Egypt/Egyptology, 17(7), 6951-6973. 